\title{
Hypermetabolic Axillary Lymphadenopathy on FDG PET/CT Due to COVID-19 Vaccination
}

\author{
FDG PET/BT'de COVID-19 Aşısına Bağlı Hipermetabolik \\ Aksiller Lenfadenopati
}

\author{
Ozlem Sahin ${ }^{1}$
}

${ }^{1}$ Necmettin Erbakan University, Meram Faculty of Medicine, Department of Nuclear Medicine, Konya, Turkey

Address correspondence to: Ozlem Sahin, Necmettin Erbakan University, Meram Faculty of Medicine, Department of Nuclear Medicine, Konya, Turkey

e-mail: drozlemsahin@gmail.com

Geliş Tarihi/Received: 9 July 2021 Kabul Tarihi/Accepted: 26 August 2021
Öz

Amaç: Bu çalışmada onkoloji hastalarında F18-florodeoksiglukoz (FDG) pozitron emisyon tomografi/ bilgisayarlı tomografide (PET/BT) COVID-19 aşılarına bağlı hipermetabolik aksiller lenf nodu insidansını ve hipermetabolik aksiller lenf noduna etki eden faktörleri değerlendirmek amaçlanmıştır.

Hastalar ve Yöntem: 15 Ocak 2021-15 Haziran 2021 tarihleri arasında kurumumuzda FDG PET/BT görüntülemesi yapılan hastalardan bir veya iki doz COVID-19 aşısı (CoronaVac veya Biontech) uygulanmış olanlar çalışmaya dahil edildi. Birinci ve ikinci aşılama sonrası ipsilateral hipermetabolik aksiller lenf nodu varlığı ve sayısı, FDG tutulumu ve bu veriler arasında fark olup olmadığı araştırıldı.

Bulgular: CoronaVac ile aşılanan hastaların \%9,9'unda (18/182) [1. dozdan sonra \%9,6 (9/94), 2. dozdan sonra \% 10,2 (9/88)]; Biontech ile aşılanan hastaların \%37,5'inde (9/24) [1. dozdan sonra \%35 (7/20), 2. dozdan sonra \%50 (2/4)] tek taraflı hipermetabolik aksiller lenf nodu gözlendi. CoronaVac uygulanan hastalarda hipermetabolik aksiller lenf nodu varlığı ile yaş arasında negatif korelasyon saptandı.

Sonuç: CoronaVac sonrası hipermetabolik aksiller lenf nodu sıklığı, çalışmamızda küçük bir hasta grubu olan mRNA aşılarından sonra gözlenenden ve literatürde bildirilenden daha düşüktü. Ancak mRNA grubunda hasta sayısının yetersiz olması nedeniyle istatistiksel fark değerlendirilememiştir. Yanlış pozitiflikleri azaltmak için FDG PET/BT'den önce kısa bir aşı anamnezi alınması önerilir. FDG PET/BT'nin farklı biyoteknolojilerle üretilen aşıların etkinliğinin karşılaştırılmasındaki potansiyel rolü, daha geniş hasta popülasyonlarında yapılacak çalışmalarla araştırılmalıdır.

Anahtar Kelimeler: COVID-19, aşılama, FDG PET/BT, aksiller lenfadenopati, CoronaVac, Biontech \begin{abstract}
Aim: This study aimed to evaluate the incidence of hypermetabolic axillary lymph nodes due to COVID-19 vaccines and the factors affecting hypermetabolic axillary lymph nodes in F18-fluorodeoxyglucose (FDG) positron emission tomography/computed tomography (PET/CT) in oncology patients.

Patients and Methods: Among the patients who underwent FDG PET/CT in our institution between January 15,2021 , and June 15,2021 , those who received one or two doses of COVID-19 vaccine (CoronaVac or Biontech) were included in the study. Presence and number of ipsilateral hypermetabolic axillary lymph nodes, FDG uptake, and whether there was a difference between these data after the 1st and 2 nd vaccination were investigated.

Results: Unilateral hypermetabolic axillary lymph nodes was observed in $9.9 \%(18 / 182)$ of the patients [9.6\% (9/94) after 1 st dose, $10.2 \%(9 / 88)$ after 2 nd dose] vaccinated with CoronaVac; It was detected in $37.5 \%(9 / 24)$ of the patients [35\% (7/20) after 1 st dose, $50 \%(2 / 4)$ after 2 nd dose] who vaccinated with Biontech. A negative correlation was found between the presence of hypermetabolic axillary lymph nodes and age in patients who vaccinated with CoronaVac.

Conclusion: The frequency of hipermetabolik aksiller lenf nodu after CoronaVac was lower than that observed after mRNA vaccines, a small group of patients in our study, and lower than reported in the literature. However, the statistical difference could not be evaluated due to the insufficient number of patients in the Biontech group. A brief history of vaccination is recommended before FDG PET/CT to reduce false positives. The potential role of FDG PET/CT in comparing the efficacy of vaccines produced with different biotechnologies should be searched in studies with larger patient populations.
\end{abstract}

Key words: COVID-19, vaccination, FDG PET/CT, axillary lymphadenopathy, CoronaVac, Biontech
Cite this article as: Sahin $O$. Hypermetabolic Axillary Lymphadenopathy on FDG PET/CT Due to COVID-19 Vaccination. Selcuk Med J 2021;37(3): 269-275
Disclosure: Author has not a financial interest in any of the products, devices, or drugs mentioned in this article. The research was not sponsored by an outside organization. Author has agreed to allow full access to the primary data and to allow the journal to review the data if requested. 


\section{INTRODUCTION}

Effective and safe vaccination seems to be the best strategy to control the coronavirus disease 2019 (COVID-19) pandemic, which profoundly affects the socioeconomic structure globally and has not yet been discovered an effective antiviral treatment. In addition to vaccines obtained by traditional methods such as inactivated vaccines, live attenuated vaccines, protein-based vaccines, viral vector vaccines, various vaccines have been rapidly developed with intense efforts in new technological platforms using DNA and mRNA fragments. In this direction, mass vaccination of risky groups in Turkey started with CoronaVac (Sinovac Biotech, Beijing, China), an inactive vaccine, on January 13, 2021. As of April 12, Biontech (BNT162b2) vaccines, which are mRNA vaccines, are applied (1).

The most common side effects of vaccines are pain, redness, swelling, itching, weakness, headache, myalgia, fever, chill, nausea, vomiting, diarrhea at the injection site, which resolves within a few days (2-4). In addition, palpable lymphadenopathy on physical examination was reported in the range of $0.1 \%$ to $1 \%$ after the mRNA vaccines, Biontech and Moderna (mRNA-1273), and the viral vector vaccine Vaxzevria (ChAdOx1-S) (5,6). Studies conducted with F18-fluorodeoxyglucose (FDG) positron emission tomography/computed tomography (PET/CT) show that unilateral hypermetabolic axillary lymph nodes (HALN) are more common than previously thought $(7.4-45.8 \%)$ (7-14). FDG PET/CT can detect postvaccine subclinical reactive lymph nodes much more reliably than $\mathrm{CT}$, magnetic resonance imaging (MRI), and ultrasound (USG) by showing metabolic changes before morphological changes. Therefore, FDG PET/ CT studies constitute most cases in which vaccinerelated lymphadenopathies are presented in the literature, and higher incidences of HALN are reported with FDG PET/CT compared to clinical studies (5-14).

Among all vaccines, mRNA vaccines provide the highest efficacy against COVID-19 but cause more side effects (2). In contrast, inactivated virus vaccines are the safest but less effective (2). Only two studies have reported lymphadenitis after CoronaVac, with a rate of $0.3-0.7 \%(15,16)$. However, there is no study in the literature showing FDG PET/CT hypermetabolic lymph node status after inactive COVID-19 vaccines. Therefore, our research aims to evaluate the frequency of vaccine-related HALNs and the affecting factors in patients who have recently received the CoronaVac vaccine and undergone FDG PET/CT for oncological purposes.

\section{PATIENTS AND METHODS}

This retrospective study was conducted with the approval of the ethics committee of our institution (decision no; 2021/3307), with the requirement for informed consent waived. Patients over 18 years old who underwent FDG PET/CT for any indication in our institution between January 15, 2021, and June 15, 2021 , who received the first or second dose of the COVID-19 vaccine (CoronaVac or Biontech) in the last month, were included in the study. CoronaVac vaccine contained SARS-CoV-2 antigen (600SU) and aluminum hydroxide $(0.45 \mathrm{mg} / \mathrm{ml})$ as an adjuvant (17). The patients' demographic data, medical diagnosis, and treatment histories were obtained from the hospital's digital archive. In addition, information about the date of vaccination, place of vaccination, and vaccine brand was obtained from all patients before imaging. Patients with previous axillary lymph node metastases or who had undergone axillary lymph node dissection and patients with HALNs on their last FDG PET/CT were excluded.

\section{FDG PET/CT Imaging and Analysis}

FDG PET/CT imaging was performed according to the European Association of Nuclear Medicine (EANM) guideline using Siemens Biograph 6 TruePoint PET/ CT (Siemens, Germany) (18). In brief, $0.14 \mathrm{mCi} /$ $\mathrm{kg}$ dose of FDG was administered intravenously to patients who had been fasting for at least six hours and whose blood glucose was $<200 \mathrm{mg} / \mathrm{dL}$. After 60 minutes, CT imaging (130 kV, $50 \mathrm{~mA})$ was performed without intravenous contrast, followed by PET images from the head to thigh for 3 minutes at the bedside. PET images were reconstructed using the iterative method. A nuclear medicine physician with 12 years of experience evaluated all PET/CT images. Maximum standardized uptake values (SUVmax) were calculated with a region of interest (ROIs) drawn on bilateral deltoid muscle and axillary lymph nodes. Deltoid and axillary lymph node SUVmax values in the injected arm were considered positive if they were greater than 1.5 times the SUVmax values on the contralateral side (19). If a HALN was detected, the length of its short axis and number were recorded in $\mathrm{mm}$. In addition, the mediastinal blood pool, spleen, and liver SUVmax values of all patients were calculated.

\section{Statistical Analysis}

Appropriate descriptive statistics were given for all variables (mean, standard deviation, frequency, and 
Table 1. Clinical characteristics of patients

\begin{tabular}{lccc}
\hline & All vaccinated $\mathbf{n = 2 0 6}$ & with CoronaVac n=182 & with Biontech n=24 \\
\hline Age & $65.8 \pm 12.1$ & $66.4 \pm 11.6$ & $60.8 \pm 14.3$ \\
Gender & $87(42.2 \%)$ & $73(40.1 \%)$ & $14(58.3 \%)$ \\
Female & $119(57.8 \%)$ & $109(59.9 \%)$ & $10(41.7 \%)$ \\
Male & $114(55.3 \%)$ & $94(51.6 \%)$ & $20(83.3 \%)$ \\
Dose 1 & $92(44.7 \%)$ & $88(48.4 \%)$ & $4(16.7 \%)$ \\
Dose 2 & & $41(22.5 \%)$ & $3(12.5 \%)$ \\
Primer & $44(21.3 \%)$ & $27(14.8 \%)$ & $6(25 \%)$ \\
Lung cancer & $33(16.0 \%)$ & $20(11.0 \%)$ & $6(25 \%)$ \\
Gastrointestinal cancer & $26(12.6 \%)$ & $22(12.1 \%)$ & $3(12.5 \%)$ \\
Breast cancer & $25(12.1 \%)$ & $15(8.2 \%)$ & $2(8.3 \%)$ \\
Genitourinary cancer & $17(8.2 \%)$ & $11(6.0 \%)$ & 0 \\
Lymphoma & $11(5.3 \%)$ & $9(4.9 \%)$ & 0 \\
Head and neck cancer & $9(4.3 \%)$ & $8(4.4 \%)$ & $1(4.2 \%)$ \\
Gynecological cancer & $8(3.9 \%)$ & $4(2.2 \%)$ & $2(8.3 \%)$ \\
Malignant melanoma & $6(2.9 \%)$ & $25(13.7 \%)$ & $1(4.2 \%)$ \\
Soft tissue sarcoma & $26(12.6 \%)$ & $65(35.7 \%)$ & $7(29.2 \%)$ \\
Other malignancies & & $117(64.3 \%)$ & $17(70.8 \%)$ \\
Indications & $72(34.9 \%)$ & & \\
Referred for staging & $134(65.0 \%)$ & & \\
Referred for follow-up & & &
\end{tabular}

percentage). T-test and two-way ANOVA tests were used in the analysis of numerical variables. The Chisquare test was used in the analysis of categorical variables. Analyzes were made with the Jamovi 1.8.4.0 program. $P<0.05$ was considered significant.

\section{RESULTS}

Out of 1206 patients who underwent FDG PET/ CT in our institution, 206 with suitable characteristics (182 of them CoronaVac, 24 of them Biontech) were included in the study. The flowchart is shown in Figure 1. The median age was $65.8 \pm 12.1$, and $42 \%$ were female. The clinical characteristics of the patients are shown in Table 1. The unilateral HALN was detected in $9.9 \%(18 / 182)$ of patients vaccinated with CoronaVac and $37.5 \%(9 / 24)$ of patients vaccinated with Biontech. Illustrative cases are shown in Figure 2, Figure 3, and Figure 4. With CoronaVac 9.6\% (9/94) after 1st dose, 10.2\% (9/88) after 2nd dose, with Biontech 35\% (7/20) after 1st dose and $50 \%(2 / 4)$ after 2 nd dose rate of HALN was seen. Since the number of patients vaccinated with Biontech was meager compared to CoronaVac, a statistical comparison could not be made between the two patient groups. Focal unilateral FDG uptake in the deltoid muscle was detected in $9.3 \%(17 / 182)$ of the patients vaccinated with CoronaVac and $16.7 \%$ $(4 / 24)$ of the patients vaccinated Biontech. All patients with asymmetric FDG uptake in the deltoid muscle had less than 14 days between FDG PET/CT and vaccination time. There was no statistically significant difference in the rates of HALN, rates of FDG uptake in the deltoid muscle, SUVmax values of all lymph nodes, and the number and size of HALNs in patients who underwent FDG PET/CT after the 1st and the 2nd dose CoronaVac. SUVmax values of HALNs were statistically higher after the 2 nd dose $(1.87 \pm 0.74)$ than after the 1st dose $(1.48 \pm 0.74)(p=0.014)$ (Table 2).

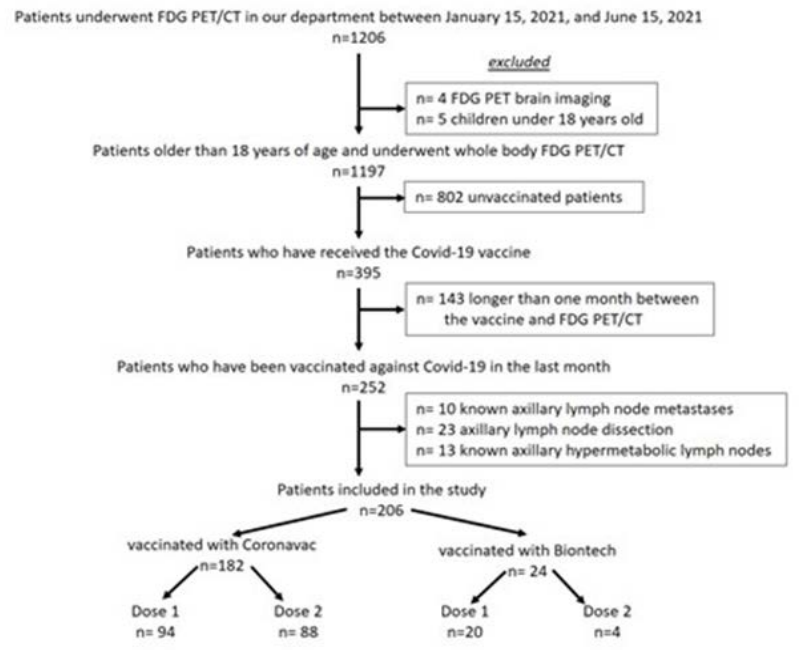

Figure 1. Flow chart showing the inclusion and exclusion criteria of patients 


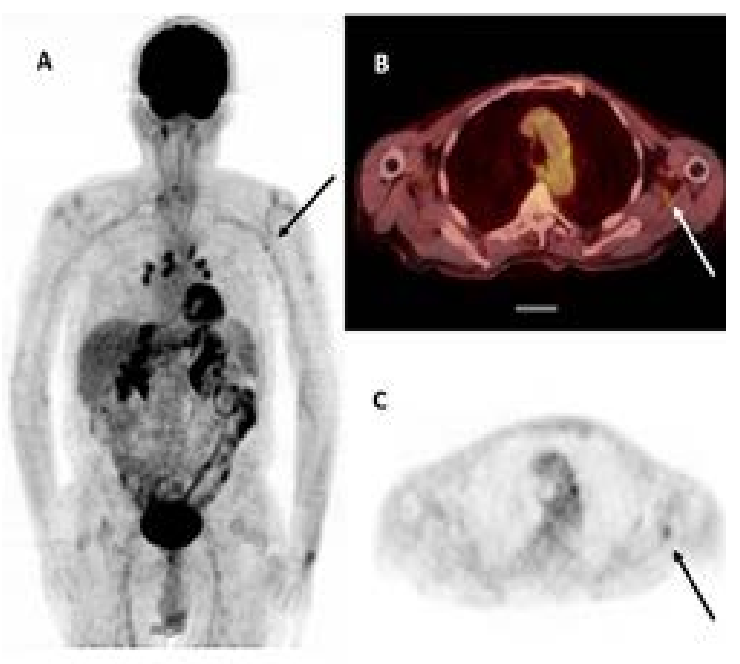

Figure 2. A 79-year-old man with diagnosed operated pancreas cancer underwent a whole-body FDG PET/CT for response to treatment; 11day after the administration dose 2 of CoronaVac showing HALN. A, PET MIP image; $B$, axial PET/CT fusion image; $C$, only PET image. Arrow, increased FDG uptake in a lymph node in the left axilla of $10 * 12 \mathrm{~mm}$, SUVmax of 3.51 .

There was no difference between patients with and without HALN in terms of gender, deltoid muscle involvement, spleen, liver, and mediastinal blood pool SUVmax values; there was a difference in terms of age $(p=0.02)$ (Table 3$)$. HALN was detected in $5 \%$ of patients over 65 years of age and in $15.9 \%$ of patients under 65 years of age who were vaccinated with CoronaVac. HALN was detected in $25 \%$ of patients over 65 and $43.8 \%$ of patients under 65 years of age who vaccinated with Biontech (Table 4). The mean SUVmax value of HALNs in patients vaccinated with CoronaVac was 1.67 \pm 0.75 ; The mean SUVmax values of HALNs in patients vaccinated with Biontech were $2.44 \pm 1.43$ (Figure 5).

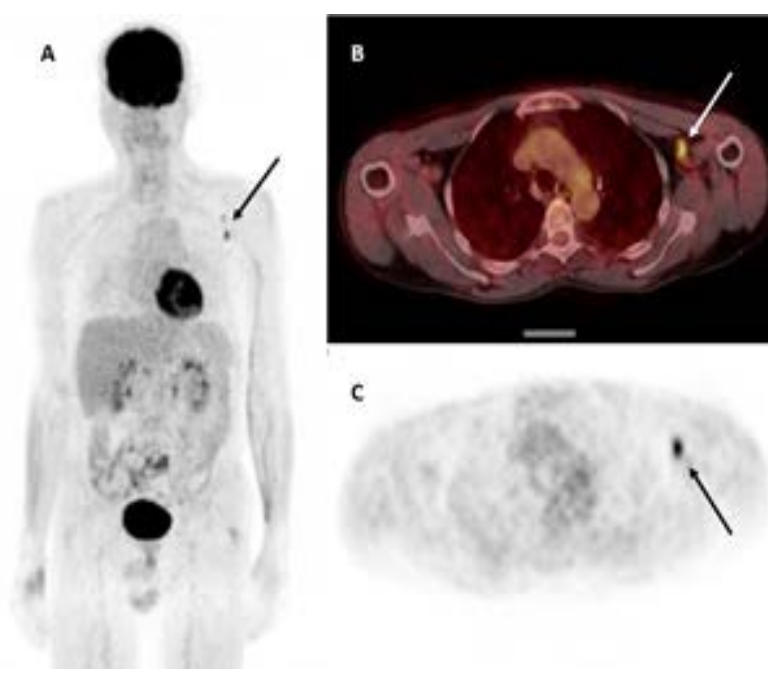

Figure 3. A 54-year-old man with diagnosed NonHodgkin lymphoma underwent a whole-body FDG PET/CT after receiving chemotherapy and radiotherapy; 11day after the administration dose 1 of Biontech showing HALN. A, PET MIP image; $B$, axial $P E T / C T$ fusion image; $C$, only $P E T$ image. Arrow, increased FDG uptake in two lymph nodes in the left axilla, the largest $9 * 16 \mathrm{~mm}$ and SUVmax 5.98 .

\section{DISCUSSION}

While globally mass vaccination studies continue in the struggle against COVID-19, the accumulation of data on the efficacy and safety of vaccines developed with different technologies continues. In this context, in our study, we observed ipsilateral HALN in $9.9 \%$ of patients after CoronaVac, which was inactivated coronavirus vaccine. This appears to be lower than previously reported rates of HALN due to mRNA vaccination (7-10,14). We did not detect any difference in the frequency of HALN in FDG PET/CTs performed after the 1 st and 2 nd doses of vaccination. However, SUVmax values of HALNs after the 2nd dose were

Table 2. FDG PET/CT data after 1 st and 2 nd doses of CoronaVac $\left({ }^{*} \mathrm{P}<0.05\right)$

\begin{tabular}{lllll}
\hline & $\begin{array}{l}\text { All patient } \\
\mathbf{n = 1 8 2}\end{array}$ & $\begin{array}{l}\text { Dose-1 } \\
\mathbf{n = 9 4}\end{array}$ & $\begin{array}{l}\text { Dose-2 } \\
\mathbf{n = 8 8}\end{array}$ & P \\
\hline HALN & $18(9.9 \%)$ & $9(9.6 \%)$ & $9(10.2 \%)$ & 0.883 \\
Deltoid & $17(9.3 \%)$ & $6(6.4 \%)$ & $11(12.5 \%)$ & 0.156 \\
SUVmax all & $1.02 \pm 0.4$ & $0.98 \pm 0.37$ & $1.06 \pm 0.43$ & 0.159 \\
SUVmax HALN & $1.67 \pm 0.75$ & $1.48 \pm 0.74$ & $1.87 \pm 0.74$ & $0.014^{*}$ \\
Diameter LN & $6.8 \pm 1.4$ & $6.67 \pm 1.22$ & $6.89 \pm 1.62$ & 0.747 \\
Number LN & $1.4 \pm 0.5$ & $1.22 \pm 0.44$ & $1.56 \pm 0.53$ & 0.165 \\
\hline
\end{tabular}

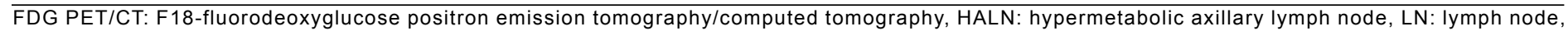
SUVmax: Maximum standardized uptake value 
Table 3. Demographic and FDG PET/CT data of patients with and without HALN vaccinated with CoronaVac $\left({ }^{*} \mathrm{P}<0.05\right)$

\begin{tabular}{llll}
\hline & $\begin{array}{l}\text { Positive HALN } \\
\mathbf{n = 1 8}\end{array}$ & $\begin{array}{l}\text { Negative HALN } \\
\mathbf{n = 1 6 4}\end{array}$ & P \\
\hline Age & $60.67 \pm 11.56$ & $67.05 \pm 11.46$ & $0.026^{*}$ \\
Gender F/M & $5 / 13$ & $68 / 96$ & 0.261 \\
Deltoid SUVmax & $1.32 \pm 0.41$ & $1.31 \pm 0.35$ & 0.88 \\
Spleen SUVmax & $3.01 \pm 0.47$ & $3.14 \pm 0.70$ & 0.43 \\
Liver SUVmax & $4.12 \pm 0.84$ & $4.07 \pm 0.97$ & 0.828 \\
Mediastinum SUVmax & $2.72 \pm 0.51$ & $2.94 \pm 0.70$ & 0.2 \\
\hline
\end{tabular}

F/M: Female/Male, FDG PET/CT: F18-fluorodeoxyglucose positron emission tomography/computed tomography, HALN: hypermetabolic axillary lymph node, LN: lymph node, SUVmax: Maximum standardized uptake value

significantly higher than the SUVmax values of the HALN after the 1st dose.

Transient inflammation caused by vaccination in lymph nodes may cause false positivities in FDG PET/CT. This can pose a clinical challenge in managing oncology patients who constituted most FDG PET/CT indications. This problem becomes more prominent, especially in malignancies that have a higher risk of spreading to axillary and cervical supraclavicular lymph nodes, such as breast cancer, lymphoma, lung cancer, malignant melanoma,

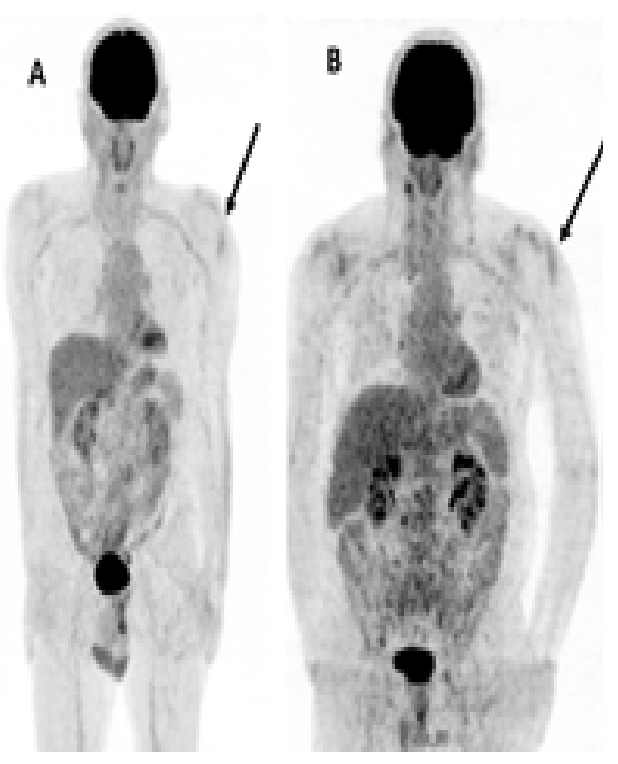

Figure 4. A; FDG uptake in the deltoid muscle in the PET/CT MIP image on the 6th day after two doses of CoronaVac of a 64-year-old patient diagnosed with bladder cancer (SUVmax: 2.34). B; FDG uptake in the deltoid muscle in the FDG PET/CT MIP image of a 58-year-old patient who was diagnosed with Kaposi's sarcoma and had the 1st dose of Biontech vaccine six days ago (SUVmax: 2.16) head and neck tumor. In a very recent publication, Skawran et al. (14) reported that they saw HALN in $54 \%(75 / 140)$ of oncology patients who received mRNA vaccine for COVID-19 and that HALN affected clinical management in $12 \%$ of patients (17/140). The Breast Imaging Society recommends deferring scans to 4-6 weeks after vaccination if possible and if will not cause a delay (20). However, this delay cannot be tolerated in most patients who performed FDG PET/ CT. If unilateral lymphadenopathy is detected within one month after vaccination, a follow-up of 4-12 weeks is recommended (20). We consider that the scope of current recommendations may change as information on the incidence and visualization times of hypermetabolic lymph nodes observed in FDG PET/CT accumulates.

Aside from the confusion caused by HALN in FDG $\mathrm{PET} / \mathrm{CT}$ in oncology patients, this entity can increase knowledge about vaccine response by visualizing the

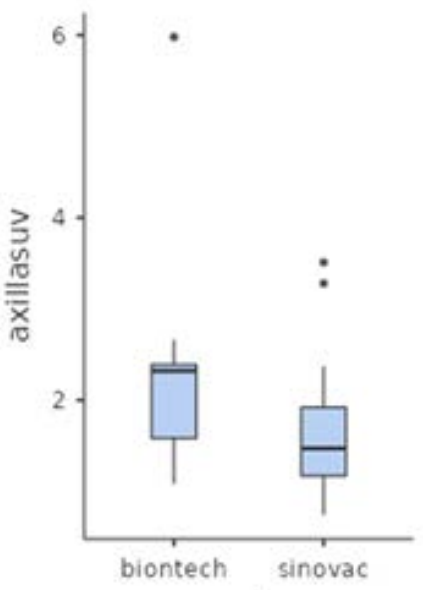

Figure 5. HALN SUVmax levels of patients vaccinated with CoronaVac and Biontech 
Table 4. HALN rates in patients over 65 years of age and under

\begin{tabular}{llll}
\hline & $\begin{array}{l}\text { Over } \mathbf{6 5} \text { years } \\
\mathbf{n = 1 0 8}\end{array}$ & $\begin{array}{l}\text { Under } \mathbf{6 5} \text { year } \\
\mathbf{n = 9 8}\end{array}$ & $\begin{array}{l}\text { Total } \\
\mathbf{n = 2 0 6}\end{array}$ \\
\hline Biontech & $2(25 \%)$ & $7(43.8 \%)$ & $9(37.5 \%)$ \\
Positive & $6(75 \%)$ & $9(56.2 \%)$ & $15(62.5 \%)$ \\
Negative & $8(100 \%)$ & $16(100 \%)$ & $24(100 \%)$ \\
Total & & $13(15.9 \%)$ & $18(9.9 \%)$ \\
CoronaVac & $5(5 \%)$ & $69(84.1 \%)$ & $164(90.1 \%)$ \\
Positive & $95(95 \%)$ & $82(100 \%)$ & $182(100 \%)$ \\
Negative & $100(100 \%)$ & & \\
Total & &
\end{tabular}

HALN: hypermetabolic axillary lymph node

spatial and temporal dynamics of immune cells in the host body after vaccination (21). It is still premature to say that this imagined inflammatory response is correlated with the vaccine's efficacy. However, the fact that $26-54 \%$ HALN rates reported in mRNA vaccines $(7-10,14)$ are higher $(5-29 \%)$ than those previously reported with inactive virus vaccines, unadjuvanted seasonal influenza virus vaccine (22) and $\mathrm{H} 1 \mathrm{~N} 1$ vaccine (23), supports this idea. In addition, Cohen et al., in their study on HALN in FDG PET/CT on patients with hematological malignancies who received mRNA vaccine, also performed an additional serological test in a subgroup (9). Accordingly, they found a statistically significant positive correlation between the presence of HALN and the anti-spike antibody titer, showing that HALN had $90 \%$ PPV in predicting serology positivity. However, they stated that their data were valid only in patients with hematological malignancies and that the absence of VAHL could not yet be said to be an indicator of impaired humoral response (9).

While studies investigating the presence of HALN in patients who were vaccinated with COVID-19 vaccines produced with mRNA technology constitute almost all of the literature in this area, there is no study yet showing the presence/frequency of lymphadenopathy in inactivated coronavirus vaccines. In our cohort, which represents the first study in this area, a shallow rate of $10 \%$ was detected compared to the frequency of HALN given in mRNA vaccines in the literature. In our research, we found higher rates of HALN in a small number of Biontech-vaccinated patients, but the patient population was not sufficient to perform statistical analysis between the two groups. Nevertheless, our data support the thesis that mRNA vaccines are more immunogenic than conventional vaccines and potentially responsible for the presence of HALN. Larger patient populations are needed to evaluate the frequency and intensity of HALN in vaccines produced with different biotechnologies, and prospective studies supported by serology are required to more clearly determine the relationship between HALN and the efficacy of the vaccine. Similar to mRNA vaccines, an inverse relationship was found between increasing age and the frequency of HALN in our study $(p=0.026)(7,8,10)$. This situation can be explained by the decrease in primary and secondary antibody responses with aging (fewer cells produce specific antibodies, fewer antibodies are produced per cell, and antibodies are less effective in preventing infection, even with sufficient antibodies) $(10,24)$.

There were some limitations in our study. We could not statistically compare the frequency of HALN after Biontech and CoronaVac, as we did not have enough patients vaccinated with Biontech. Since our patient group consisted of only oncology patients, there may exist publication bias. Vaccine-related HALN is based solely on clinical observation, and pathological confirmation was not performed in any patient.

\section{CONCLUSION}

The frequency of HALN, which can cause false positives in FDG PET/CT, is lower with inactivated Coronavirus vaccine than with mRNA vaccines. We recommend including the information about the time of vaccination, the brand, and localization of the vaccine in the anamnesis taken from the patients before imaging, and the physician interprets in the light of this information. In addition, if the patient has a known lateralized upper body malignancy at the time of vaccination, choosing the opposite arm for vaccination will reduce confusion on this issue. The clinical value of FDG PET/CT in demonstrating the efficacy of vaccines produced with different biotechnologies is an exciting and important area that needs to be investigated with more data. 
Conflict of interest: Authors declare that there is no conflict of interest between the authors of the article.

Financial conflict of interest: Authors declare that they did not receive any financial support in this study.

Address correspondence to: Ozlem Sahin, Necmettin Erbakan University, Meram Faculty of Medicine, Department of Nuclear Medicine, Konya, Turkey

e-mail: drozlemsahin@gmail.com

\section{REFERENCES}

1. COVID-19 Aşısı ulusal uygulama stratejisi, T.C. Sağlık Bakanlığı COVID-19 Aşısı bilgilendirme platformu. 4 Temmuz 2021'de ulaşıldı. https://covid19asi.saglik.gov.tr/TR-77706/ covid-19-asisi-ulusal-uygulama-stratejisi.html

2. Cheng $H$, Peng $Z$, Luo $W$, et al. Efficacy and safety of COVID-19 vaccines in phase III trials: A meta-analysis. Vaccines 2021; 9:582.

3. Palacios R, Patino EG, de Oliveira Piorelli R, et al. Doubleblind, randomized, placebo-controlled phase III clinical trial to evaluate the efficacy and safety of treating healthcare professionals with the adsorbed COVID-19 (Inactivated) vaccine manufactured by Sinovac - PROFISCOV: A structured summary of a study protocol for a randomised controlled trial. Trials 2020;15;21:853.

4. Keshavarz $P$, Yazdanpanah $F$, Rafiee $F$, et al. Lymphadenopathy following COVID-19 vaccination: Imaging findings review. Acad Radiol 2021;28(8):1058-71.

5. Brown A, Shah S, Dluzewski $S$, et al. Unilateral axillary adenopathy following COVID-19 vaccination: A multimodality pictorial illustration and review of current guidelines. Clin Radiol 2021;76:553-8.

6. Polack FP, Thomas SJ, Kitchin N, et al. Safety and efficacy of the BNT162b2 mRNA Covid-19 vaccine. N Engl J Med 2020;383:2603-15.

7. Bernstine $\mathrm{H}$, Priss $\mathrm{M}$, Anati $\mathrm{T}$, et al. Axillary lymph nodes hypermetabolism after BNT162b2 mRNA COVID-19 vaccination in cancer patients undergoing 18F-FDG PET/CT: A cohort study. Clin Nucl Med 2021;46:396-401.

8. Cohen D, Krauthammer SH, Wolf I, et al. Hypermetabolic lymphadenopathy following administration of BNT162b2 mRNA Covid-19 vaccine: Incidence assessed by [18F]FDG PET-CT and relevance to study interpretation. Eur $\mathrm{J} \mathrm{Nucl}$ Med Mol Imaging 2021;48:1854-63.

9. Cohen D, Krauthammer $\mathrm{SH}$, Cohen $\mathrm{YC}$, et al. Correlation between BNT162b2 mRNA Covid-19 vaccine-associated hypermetabolic lymphadenopathy and humoral immunity in patients with hematologic malignancy. Eur J Nucl Med Mol Imaging 2021;8:1-10.

10. Eifer M, Tau N, Alhoubani $\mathrm{Y}$, et al. Covid-19 mRNA vaccination: Age and immune status and its association with axillary lymph node PET/CT uptake. J Nucl Med 2021;23:jnumed.121.262194.

11. Eshet $Y$, Tau N, Alhoubani Y, et al. Prevalence of increased FDG PET/CT axillary lymph node uptake beyond 6 weeks after mRNA COVID-19 vaccination. Radiology 2021;27:210886.

12. Schroeder DG, Jang $S$, Johnson DR, et al. Frequency and characteristics of nodal and deltoid FDG and 11C-Choline uptake on PET imaging performed after COVID-19 vaccination. AJR Am J Roentgenol 2021 May 19. doi:
10.2214/AJR.21.25928.

13. Shin M, Hyun CY, Choi YH, et al. COVID-19 vaccinationassociated lymphadenopathy on FDG PET/CT: Distinctive features in adenovirus-vectored vaccine. Clin Nucl Med 2021 Jun 10. doi: 10.1097/RLU.0000000000003800.

14. Skawran S, Gennari AG, Dittli M, et al. [18F]FDG uptake of axillary lymph nodes after COVID-19 vaccination in oncological PET/CT: Frequency, intensity, and potential clinical impact. Eur Radiol 2021;22:1-9.

15. Zhang MX, Zhang TT, Shi GF, et al. Safety of an inactivated SARS-CoV-2 vaccine among healthcare workers in China. Expert Rev Vaccines. 2021;13:1-8.

16. Djanas D, Yusirwan, Martini RD, et al. Survey data of COVID-19 vaccine side effects among hospital staff in a national referral hospital in Indonesia. Data Brief 2021;36:107098.

17. İnaktif Pandemik COVID-19 aşısı CoronaVac'ın içeriği nedir? T.C. Sağlık Bakanlığı COVID-19 Aşısı Bilgilendirme Platformu. 4 Temmuz 2021'de ulaşıldı. https://covid19asi. saglik.gov.tr/TR-78241/inaktif-pandemik-covid-19-asisicoronavacin-icerigi-nedir.html

18. Boellaard R, Delgado-Bolton R, Oyen WJ, et al. European Association of Nuclear Medicine (EANM). FDG PET/CT: EANM procedure guidelines for tumour imaging: Version 2.0. Eur J Nucl Med Mol Imaging 2015;42:328-54.

19. Thomassen A, Lerberg Nielsen A, Gerke O, et al. Duration of 18F-FDG avidity in lymph nodes after pandemic H1N1v and seasonal influenza vaccination. Eur J Nucl Med Mol Imaging $2011 ; 38: 894-8$

20. The society of breast Imaging patient care and delivery committee. SBI recommendations for the management of axillary adenopathy in patients with recent COVID-19 vaccination. Updated January 16, 2021. Accessed July 03, 2021. https://www.sbionline.org/Portals/0/Position $\% 20$ Statements/2021/SBI-recommendations-for-managingaxillary-adenopathy-post-COVID-vaccination.pdf

21. Youn $\mathrm{H}$, Hong KJ. Non-invasive molecular imaging of immune cell dynamics for vaccine research. Clin Exp Vaccine Res 2019;8:89-93.

22. Shirone $\mathrm{N}$, Shinkai T, Yamane $\mathrm{T}$, et al. Axillary lymph node accumulation on FDG-PET/CT after influenza vaccination. Ann Nucl Med 2012;26:248-52.

23. Burger IA, Husmann L, Hany TF, et al. Incidence and intensity of F-18 FDG uptake after vaccination with $\mathrm{H} 1 \mathrm{~N} 1$ vaccine. Clin Nucl Med 2011;36:848-53.

24. Castle SC. Clinical relevance of age-related immune dysfunction. Clin Infect Dis 2000;31:578-85. 